\title{
Understanding the Effects of COVID-19 on Universities in South Africa: An Evidence- Based Approach
}

\section{Zwelinzima Ndevu \\ ORCiD ID: https://orcid.org/0000-0003-2991-8424}

\begin{abstract}
The current COVID-19 pandemic which has affected all sectors of society, has not spared South Africa. The initial lockdown initiative by the government to flatten the curve and reduce the spread of the virus was well received, but as time passed, and the effects of lockdown were experienced, the impacts have proved to have some negative results. The country's higher education authorities took the decision to continue online with the academic year, against the traditional face-to-face teaching and learning system. This article concentrates on the impact of COVID-19 on higher education and considers the challenges on the learning environment for students and academic staff. The article is based on the qualitative, interpretative empirical framework, which reflects on the content analysis of primary and secondary sources, and six interviews conducted with purposely selected academics, from three universities in South Africa. The interviewees identified critical concerns which must be considered as they reflect problems faced by the students and academics at all levels. The analysis is informed by the logic of evidence-based policy making.
\end{abstract}

Keywords: education, COVID-19, learning, challenges, on line learning, evidence-based approach 


\section{Introduction and Context}

The spread of COVID-19 throughout the world had an immense negative effect on all aspects of human life and action, in institutions, organisations, communities and families, as social interaction, a key element of human society, became a memory of the recent past. Inevitably, the educational sector has not been immune, despite the medical science showing that younger populations appear to be in a lower mortality risk category when compared to older adults (Salovey 2020b). The precautions emanating from the pandemic were associated with what has been called 'physical distancing' or/ and 'social distancing', or behaviours that were advised and adopted by the majority of the population wishing to continue living. The rationale was to reduce human to human transmission in highly populated geographical spaces or social networks that are dense, including university campuses (Salovey 2020a; Salovey 2020b). The response to COVID-19 has had extremely serious repercussion for higher education throughout the world in terms of perpetual uncertainties that have led to functional and structural economic and social problems and challenges at all organisational and institutional levels (Adam, Henstridge \& Adam 2020; Gerszon, Mahler, Castaneda \& Aguilar 2020) The response by universities globally, has been to rapidly amend policy, and implement strategies which would allow for learning to continue through electronic platforms. This called for collective agreements undertaken by all stakeholders and role players (university leaders, managers, academic and administrative staff, students, and institutional councils) to ensure that this was made possible, quickly, in order to facilitate the transition from face-to-face classes to online learning systems (Lederman 2020). This article examines the impact of COVID-19 on higher education and considers the challenges on the learning environment for students and academic staff, through an evidencebased approach.

\section{Evidence-Based Decision Making}

Evidence-based decision-making is considered a process instrumental in leading to decisions with regard to a practice or a policy that is chosen. It is grounded in the logic that empirical research evidence, as well as existing relevant field experiential learning and relevant contextual evidence assist in understanding a situation and taking relevant actions. The theory has become the basis of a wide variety of social science and administrative disciplines, and 
has been utilised extensively in policy decision making. The overall logic is that relying on evidence allows for informed decisions. The contributions of practitioners, researchers, entrepreneurs, discipline specialists, politicians or administrators who are able to offer the most detailed and comprehensive view of the evidence that is expected to strengthen the researcher's information, are considered most suitable. When the collection of such information is complete, the synthesis and analysis of the information is the foundation of decisionmaking processes (Pfeffer \& Sutto 2006). Within this process, the collection of information based on experience and knowledge in order to lead to the appropriate and well researched decision-making, is based fundamentally on three directly related dimensions: the best available evidence, the contextual evidence, and the experiential evidence. Their collection and utilisation lead to evidence-based decision-making (Stanford Social Innovation Review 2020).

Such a process begins with the gathering of the best available research evidence through the collection of contextual information on factors that are considered to be of key importance for the decision, hence the careful attention to the stakeholders' knowledge, expertise, connections and honesty. The interpretation of the evidence leads ultimately to the application of what has been learnt as it is expected that the three types of evidence are substantial enough to provide solutions to existing problems and challenges (Baba \& Zadeh 2012:833-834).

During the application of the evidence stage, the consideration of all collective sources of evidence takes place, then evidence is analysed, dissected, and thought about very seriously, until the decision is taken for it to become prioritised and transformed through a serious and comprehensive deliberation of the research group that could lead to an actionable decision. Such a decision process must be characterised and rooted in the fundamentals of ethical thinking, accountability, cooperation, coordination, synergy, transparency, openness, explicitness, skilled leadership and a well-planned, debated, clearly defined and agreed upon facilitation process (Perkowska 2020). The logic of evidence-based decision making is used as a guide to examine the strategies adopted to move on line teaching at the onset of the pandemic.

\section{Research Method}

An inductive-theory generalisation approach was followed based on the knowledge, understanding and experiences of six academics that have direct 
experiences of universities and online teaching challenges during the closure of all universities in the country because of the coronavirus pandemic, together with details regarding the pandemic, as documented in the media. The interviewees represented three South African universities based in two provinces (two representatives each from a traditional, a comprehensive and a university of technology). The choice was based on the judgemental sampling paradigm and the interviews were open-ended. The thematic content analysis examined the realities of experiences of key stakeholders and role players at the universities and utilised the experience, knowledge and understanding, the successes, failures and challenges emanating from their personal and professional experiences. Anonymity and confidentiality were guaranteed to the interviewees.

Inductive reasoning is a method of reasoning in which the premises are viewed as supplying some evidence for the truth of the conclusion. It is also described as a method where one's experiences and observations, including what are learned from others, are synthesized to come up with a general truth (Alexandiris 2006; Saunders, Lewis \& Thornhil 2012; Lodico Spaulding \& Voegtle 2010; Neuman 2003; Bernard 2011; Goddard \& Melville 2004).

\section{Findings}

\section{The Response to the Pandemic}

The hard lockdown included regulation on the movement of people and imposed a quarantine or self-isolation, social distancing, restrictions of movement, closure of places that attracted large crowds such as gymnasiums, pubs and night clubs, restaurants, casinos, museums and movie theatres, and included the shutdown of the whole landscape of education, from crèches to universities and technical colleges, as part of the effort to curb the spread of COVID-19. Universities and their staff were obligated to observe the lockdown, and their campuses and operations at all levels were overhauled, including lectures, seminars, tutorials, contact teaching, conferences, graduation ceremonies and research workshops. Throughout the country, all students were instructed to return home, and staff were instructed to work remotely through the utilisation of online teaching mechanisms. Although there were a small number of sporadic attempts by a handful of students to declare their determination not to leave their institutions, eventually the majority of them left their universities for home (Mapanga 2020). The South 
African government was clear that the academic year would not be lost, which resulted in various responses by institutional leadership.

\section{The National Institutional Leadership Response}

The emergence of the pandemic and the first confirmed death were instrumental in changing the lives of everyone in South Africa. Universities, their students, staff, parents, and everyone involved in their functions and operations were no exception. Under such circumstances, the first thought was how the future of millions of young people would be guaranteed, what steps were required, and how operations would be delivered under such unanticipated challenging, and even frightening, circumstances. The major issue was the appropriate delivery of the academic programme. Universities South Africa (USAf), the membership organisation representing all universities in the country, coordinated and guided the processes required as it was understood that after the first national lockdown became an everyday reality, the most important issue for the higher leadership echelons of the national ministry and all 26 institutions, was to find the best way forward. Such a path of thinking, planning and implementing had only one target: embarking on teaching and learning innovations aiming at salvaging the academic year ahead (USAf 2020). This was an inevitable step forward as the Minister of the Department of Higher Education and Training was clear from day one, that the government's aim was to save the academic year, but there was a responsibility to save lives, hence students would not return to their campuses (Mapanga 2020). The Minister indicated that the department was in the process of implementing a 'risk-adjusted programme', without campus-based academic activity throughout the tertiary institutional terrain, including universities and Technical Vocational Education and Training (TVET) colleges. The reason for the decision was that the risks for the lives of 2,5 million students was too great for the institutions to operate successfully, given the opportunity at the appropriate time to plan and implement critical interventions such as multimodel remote learning systems that are effective at all levels. Such systems should be based on analogue, digital, and physical delivery of learning materials at all levels and this meant that all tertiary institutions were obligated by circumstances to ensure that they forged agreements with mobile operators to guarantee universal access deals for their students. Students expected to be provided by their institutions with material for instruction, as well as 
distribution of laptops and other devices for all students with National Students Financial Aid Scheme (NSFAS) assistance. The Minister assured all South Africans that there would be stimulus, possible relief, or emergency funding for public institutions in distress (IOL 2020).

USAF's facilitation of a meeting and a briefing by the National Institute for Communicable Diseases (NICD) to all vice-chancellors, regarding COVID-19 and its serious individual, group and societal repercussions followed. The University of Pretoria took medical advice and temporarily disabled the biometric access systems on all its campuses. The University of the Free State established a coronavirus task team composed of stakeholders from executive management, students and infectious diseases experts. The University of KwaZulu-Natal launched a 'war room' as a way of tackling the outbreak, led by its College of Health Sciences, which instituted surveillance, prevention and response measures for detection. Stellenbosch University and the University of Cape Town set up a business continuity management coordinating committee responsible for responding to the virus. The Central University of Technology established an incident-management task team as a proactive step. Rhodes University established a coronavirus task team to direct the university's preventative measures (Makupe 2020). The only group of students excepted from the ministerial directives were the final year medical students, who would return under serious control circumstances 'under strict conditions for 'in-service training' (Makupe 2020). The student return to hospitals would include active participation in examination of COVID-19 cases as the virus continued to spread very rapidly.

Given the realities of the tertiary education landscape in South Africa, it can be understood that all Higher Education Institutions (HEIs), even those institutions which, because of their history and present serious challenges, had to delve into new territories of advancement although they were aware that they are not ready or/and capable of venturing into remote teaching/learning. This reality meant that they felt the necessity of gearing their path into the future for a multiplicity of reasons, the most obvious being what was thought to be a protracted lockdown and the continuous and challenging, deadly uncertainty of the pandemic's future trajectory. The inevitability of cooperation, collaboration and synergy amongst the different institutions would and could ultimately lead the process and the continuity of sharing existing resources and information. They could debate, collaborate on solutions enhancing teaching, learning and research, look jointly for innovative 
steps forward in terms of the curriculum and the best ways for it to be delivered. Such undertakings can only be progressive steps towards enhancing emergency teaching. The delivery of learning devices for students in time in the continuous efforts to overcome the sector's need for data, was a challenge facing institutions with limited resources. Such institutions can be assisted through creative solutions, especially with students who reside in faraway localities (USAf 2020).

USAf has been adamant from the start that all universities not only made a serious effort to uphold their core functions, but had responded fully to their local contexts and cooperated fully with the government, the health designated authorities, other existing systems, the engineering and biomedical industries, multi-national organisations and civil society organs, in their honest efforts to find solutions to the pandemic. In addition, the institution became instrumental in the efforts to spread and share the realities and resources of remote teaching, learning and research, through reports of how universities ought to navigate Emergency Teaching and Learning in these circumstances.

\section{The Student Experiences}

There is no debate on the issue that COVID-19 has put once more on the agenda the demand for equity and access as the students, together with their academic mentors faced once again the clear life- lines of an unequal educational system 26 years after the dawn of democracy in South Africa. The message from the majority of students, their teachers and mentors and the tertiary institutional leadership is that such problems rooted in the past history of the country need to be faced with new political will and fresh strategic and tactical intent. This despite the fact that according to the official estimate of the DHET Minister the pandemic's financial impact on SA universities was standing at over R3.8bn in mid-August 2020 (Human Sciences Research Council 2020)

The re-imagination of an institution of tertiary education based on the fundamental of South Africa's Constitution and the National Development Plan need to be founded on the lessons, impact planning the way forward for a future founded on equity and access, equality, social and economic justice and the expansion of democracy at levels. In the minds and hearts of students, especially the poor and the marginalised is whether the crisis facing their Universities is a short-term, medium- or long-term realities facing them, 
because they are aware that the existence of financial resources is of crucial importance at all levels. Students, their families and university leaderships are fully aware that all universities are functional or dysfunctional because of their financial situation that in the final analysis determines whether the necessary shift to on-line teaching and learning demands very substantial investments in all aspect of the technological landscape that would guarantee a proper teaching and learning preparation that guarantees the safe return of student in the campuses. Both are significantly capital intensive. These realities are directly and indirectly related with the two interrelated aspects of the country's financial crisis both in its short, medium- and long-term realities that have basically hit the poor and the marginalised (World Bank 2019).

In today's South African realities, the key question of long term financial and fiscal sustainability at all levels is of fundamental importance for university students as the possibilities of government subsidy cuts in university and research funding together with the continuous impoverishment of poor and middle-class families will have a negative effect on present and future students. All of these possible realities have and will continue to have serious negative repercussion on the future of universities and their students at all levels (Locatelli 2018; Stein 2019:144).

Inevitably, while universities throughout South Africa have been obligated to provide- lectures online with the objective of saving the academic year, the key issue identified by the interviewees was the reality of 'rich', 'poor' and the 'middle', identifying social groups of students in all institution's representative of the existing class and 'race' realities in the country. There was a common understanding and knowledge of all interviewees pointing out that what has been called the 'digital divide' was basically rooted in the existence or not of stable internet connections and direct/indirect access to hardware. There were two different groups related to these: those who had it and those who did not. The other important reality was that those who did not have them were those living in deep or semi-rural areas, faraway townships or/and urban informal settlements. As one on the interviewees from the traditional university pointed out:

The realities for poor students, especially those in the first and second year and many postgraduates were harsh because they faced two key battles, to save the year, and to survive. We had direct contact with numbers of them throughout the country and we saw it all, it was really 
tough, it is difficult to try to find food and money for data and facing what we call focus to pass the year as the university leaderships declared, following the line of the Department of Higher Education. It is easy to talk and preach when you are not aware of the realities young people face in many ways, especially away from the city and the university surroundings and facilities.

There was an agreement amongst all interviewees that one of the most important setbacks within the new environment of technological direction to new knowledge was the disparity that existed amongst students that was a deterrent to the feasibility of innovations. Access to adequate resources, it was believed, is the key to what was described as a 'heavily locked door'. The internet was the epitome of this locked door in this case. Those academics attempted unsuccessfully to understand why a number of the student in their two universities refused to travel to their homes until they were coerced to accept defeat because it was difficult to understand the uncertainty of young students and their fear of possible failure, given the lack of a promised but not delivered laptop and enough data for their small cellular telephone. They knew well what was expected of them, they felt they had the potential, but they lacked the resources. The reality of passing the academic year became a nightmare. It became known that at least one of the three universities represented in the sample tested in one way or another, the readiness of the student to participate on the online teaching and learning exercise, as the university's leadership had realised the importance and difficulties associated with such a major challenge ahead. The problem faced by the same leadership as the interviewee confessed, was that before students responded to this exercise the university had already starting preparations for the teaching programmes of the online classes. It is a reality that such preparations have been thought to be routine for the research universities with lecturing staff and enough preliminary training in utilising existing technological systems and online teaching instruments.

The Minister of Higher Education made it clear that all students registered for NSFAS were guaranteed laptops and free data so that they would be enabled to move forward in their studies and pass the year (Van der Merwe 2020).

There was a division of opinions amongst the respondents in respect of their knowledge depending on the above issue. Both respondents from the 
comprehensive university were clear that a number of students had received data while many had not. There was the knowledge that the Ministry had notified the public, the universities and the students that the purchase of the laptops would be through tenders, hence the delays were expected, but students had serious problems as both of them, especially the most vulnerable ones, felt that they were left behind by both the universities and the Ministry. As one of the interviewees said:

Students complained in e-mails, telephone calls, social media that they lost valuable academic time and they felt there were perpetually behind and most time was used to catch up. This was mostly evident amongst Honours and Masters through course work and a good number indicated that using their phones for identifying references, sources and typing assignments was extremely difficult and time consuming. The only thing I could do was encourage them to continue, tell them am available anytime as are my colleagues. The question to be asked is how useful is such an offer. This because I and all of us know that under such circumstances, the lectures that are offered on the online meeting platform are on many occasions not the best in quality because the disadvantage is that due to poor connectivity, they just cut in the middle of the lecture. Sometimes the audio is not audible.

One of the interviewees from the University of Technology indicated that this was the case with students who left the university's residence and moved to learning at home: a reality that had serious negative effects of their study patterns despite the fact that they had high performances during the year. The key issue was the serious battle to work under a new, completely different environment surrounded by a number of family members in a relatively small house. The sharing of limited space available then had negative effects, while the fact that they could only afford small phones with very limited storage created very serious connectivity problems. These student realities, it was said, created additional scholastic and human problems for the lecturers who had the duty and responsibility to help in dealing with such student problems and challenges, spending hours in their efforts to assist students in accessing online platforms. Such efforts were concentrating on the fight, sometimes without success, because it is understood that most of these students in need have been 
left in such a situation not because of their own fault. Most of these students were determined to learn and they did not wish to fail or drop out. Despite the challenges, they were determined to succeed. Another interviewee from a University of Technology, was adamant that there was no hope for students who have been struggling financially and without resources because of the fact that remote learning cannot be managed without equipment and data, and those students who end up using their cellular telephones are forced to drop out because the connections are of poor quality, the electronic mail systems are dysfunctional and they have life survival problems. This means that the teaching and learning processes and their success are vital for both learners and lecturers, but what are also crucial are the circumstances under which the learners learn and participate in the process, their home environment, and the realities of their circumstances. The reality that surfaced was the shortage of data amongst students; in most cases this simply meant that students were unable to submit assignments on time and such realities led to a lack of productivity. Another problem that was described as serious by the interviewees was the position of the universities towards the large number of their international students, the vast majority of whom had paid more than double when compared to locals, and were facing problems at all levels that could easily lead to psychological problems and fears for their well-being in general. As the present times have been uncertain for everyone, it was felt that the university leadership needed to use the evidence of the experiences of students in order to be able to respond more effectively through their decisionmaking systems to the needs and plight of students.

\section{The Teaching Staff Experience}

There were challenges faced by university teaching and learning processes which management had to respond to at different levels in their respective institutions. All interviewees, with one exception, were adamant that the support that staff was promised, was realised adequately. The university leadership at all levels promised students, parents, communities and society at large, that the online work would be supported fully with all appropriate tools and the whole teaching experience would lead to learning as good as the 'faceto-face' one (Husby \& Modinos 2020: 185). Internationally and in South Africa, contact university academic staff have admittedly limited experience 
or/and training in the pedagogical design, planning and implementation based delivery of online teaching and learning (Powell 2020: 420). Such realities lead to the inevitable conclusion that academics with the new 'pandemic-based' teaching responsibilities, have been obligated by realities and circumstances to upskill non-existing knowledge of new teaching methods, teaching and learning platforms familiarity with ever-increasing levels of administrative responsibilities, in the context of a societal complete closed-down of almost every aspect of human society around them. Such initiatives faced challenges including the realities faced by one of the comprehensive universities in the country, where there was an outright rejection of the on-line planned teaching (Molosankwe 2020)

It was agreed that the environment created for the staff and students was conducive to teaching, but the reality was different, as one interviewee from a traditional university explained:

It is easy for the senior leadership and management of a university to claim success and thus undermine the fact that this success is not complete at all levels, for both students and lecturers. Students have major problems, especially the poor ones and those living in places without electricity, but one needs to understand the realities of the lecturers, because these challenges are really new and not all lecturers and professors are technology experts, most of us with the new duties were really unaware that online teaching is such a long process, it is different, it is demanding because it revolves around different methods, structures, processes, strategies that need to be passed on to the teaching staff. This means that lecturers have to learn new techniques, new things, and new experiences, hence there is the need for training. We have kept in touch with our colleagues everywhere through the unions and those with who we have collaborated over the years. Everyone told us that there has been very limited training all over the place or no training at all. There were a number of colleagues who told us that they were trained for three hours and five hours, both of them in traditional universities, and then we were told that a few other were trained for two to three hours, days after they were obligated to start the online teaching. These are the realities of the whole situation. Lecturers were trained for one or two hours, after a number of weeks of remote learning roll-out. 
Another interviewee from the traditional university indicated that in the past and at present, the reality that even full professors had not received serious and comprehensive training is a reason for them struggling with the transition. This means that a lecturer does the serious background work on a specific topic, transforms it into a well-presented slide presentation and readings with footnotes and references, and the students are requested to deal with what they are given. This means that that such a presentation is not extensive enough to significantly cater for the overall and extensive range of the requirements and advanced learning needs of the majority of students. A similar position was expressed by an interviewee from the comprehensive university, who was clear that the problem with this issue differed from one institution to the other for a number of realities related to not only the problems of the lecturers but primarily those of the students, as social inequalities that have widened, made it very difficult for the students who have to cope with a lack of resources.

These and other challenges throughout institutions could possibly be debated, planned and transformed into efforts at all levels towards reviewing the year's calendar, but such an initiative could be thought of as 'tough', 'difficult', 'time- consuming', 'impossible' or even 'extreme'. Such questions were extended to cover the reality that at all universities there were students who, because of their study choice, are obligated to be directly involved in laboratory experiments and practical's. A wide variety of modalities were also needed to be considered by university leaderships very carefully. There was agreement amongst employees of comprehensive and Universities of Technology that in most cases, the challenges facing academics in relation to issues of assessment and evaluation methods in the online arrangement were a major problem for the leadership of their institutions, because of the fact that the timing of such processes were questionable, and was related to the facilitation of the first semester examinations. The present reality dictated continuous assessments based on the online teaching, meaning that the university leadership ought to be prepared for introducing processes of planning and implementing new methods in teaching and administering the outstanding tasks dealing with new assignment projects and other assessments. These did not exist, and if there were beliefs that they did, the interviewees stated, the student monitoring was seriously problematic because of the possibilities and probabilities of student cheating in online examinations and/or tests. At a more human level, there was also agreement by four of the six interviewees, that the reality of life disruption and relentless workload had 
serious negative repercussions on the lives of academics, because of the everyday with data, technology, students, data delays and cut off, assessment and monitoring, all which are creating high levels of anxiety about the present, and the uncertainty of the future.

Lecturers at the traditional and the University of Technology indicated that, a number of the programmes and devices in their on-line operations were dysfunctional and there was a belief that webinars would be a better strategy for the future. It was also stated that one of the key issues for the academic staff of these institutions was the belief that students have high expectations, a reality that has created problems. It was stated that a lack of lecturing assistants and tutors, who could be of help in such operations, exacerbated the existing problems. These realities, it was stated, seemed to have very negative effects on first year students who were struggling to adapt to the online system, and this created a major timing problem for lecturers because of the instructions to email all students who seemed to have extremely limited or had no online activity for a one to-one consultation. It was stated that, the lecturers in these electronic letters indicated that they appreciated the fact that the online learning transition was possibly an overwhelming experience and, in the process, they welcomed direct contact from the students, so all didactic challenges and problems associated with any particular module or the workload could be dealt with. It was also mentioned that a plan for continuing with teaching was necessary and, that, in case the letter was not responded to, it would be repeated. It was felt that such relations and undertakings were extremely timeconsuming for the lecturers. The traditional university interviewees complained that it was an essential to deal with the issue regarding the very extensive amount of additional work required from lecturers in fulfilling their responsibilities through notes on slides and guiding students through content. The same could also be said about the assessment process and its outcomes because it required additionally work, honesty and validity at all levels. These realities are limiting the ability to use synchronous learning, hence the lecturers are obligated to produce well researched and structured lectures. On the other hand, lecturers have to face flooded email boxes because students sometimes do not find the information they are looking for in the first line of an email. Such realities, it was said, were very time-consuming weekly when work had to be prepared and delivered for a number of modules. It was stated that these conditions of lecturers' overtime work had significant negative family and psychological challenges. 
The possibilities of alternatives to the present situation was a theme and difficult to deal with because of what was described in general as the 'bureaucratic realities' of the system, both in its 'totality' and its 'systemic components' (the 26 institutions). There was a common belief and understanding amongst all interviewees that there were and there are still, possibilities and probabilities for a number of alternatives that can only become a reality if all stakeholders and role players are prepared and eager to debate them and make decisions in an engaging and sincere manner. Re-working existing realities can lead to new decisions that can work in term of both curriculum and academic calendar transformation.

\section{Conclusions}

Throughout the various stages of the pandemic, the South African political leadership has ensured the country's population that both during and after the pandemic the government will ensure a thorough and well planned 'kick-start' of the economy through the utilisation of billions of rands (National Treasury2020a; 2020b). One reality that cannot be denied is that the participation of university leadership, academics, and research and administrative staff, is a requirement in the struggle towards combating the pandemic. This article, through its reflections on the analysis of data collected, has highlighted some of the problems and challenges faced by stakeholders and role players at institutions of higher education. Among others, the article showed that access to financial resources, a vital ingredient in increasing the possibilities of an effective response. The research findings further indicate that a key to success in the future depends primarily, but not exclusively, on the acquisition and maintenance of resources that lead to financial sustainability by institutions of higher education. For this to be achieved, the inevitability of increased state funding, and the pursuit of third-stream income cannot be ignored. This article has shown further that, through a reflection on the experiences of students and academic staff, that COVID-19 has encouraged inter-disciplinary and trans-disciplinary efforts towards finding solutions for the move to online learning, which reflects a payer of interdisciplinarity arising out of the crises presented by the pandemic.

Inevitably the future for South African institutions of higher education relies primarily on the ability of their leadership to manage the existing serious challenges, and to think, debate and plan the future. Such a future can only be 
successful when research on the successes of the past and present are studied seriously so that the planning of an innovative, transformative institution can be built or re-built. Analysis of short-term challenges and problems, through the evidence currently being produced through the various experiences of those who make up these institutions, will offer an opportunity to design plans for greater reliance.

\section{References}

Adam, C., M. Henstridge \& S. Lee 2020. The Impact of Global Economic Disruption is as Big a Threat to Low-income Countries as the Direct Effects of COVID-19. VOX, Department of Development Economics, Oxford University, 08 September. Available at:

https://voxeu.org/article/impact-global-economic-disruption-big-threatlow-income-countries-direct-effects-covid-19

(Accessed 22 October 2020)

Alexandiris, K.T. 2006. Exploring Complex Dynamics in Multi Agent-Based Intelligent Systems. Ann Arbor: ProQuest.

Baba, V.V. \& F. HakemZadeh 2012. Toward a Theory of Evidence-based Decision making. Management Decision 50,5: 832 - 867. https://doi.org/10.1108/00251741211227546

Bernard, H.R. 2011. Research Methods in Anthropology. $5^{\text {th }}$ Edition, Lanham: Alta Mira Press.

Gerszon, D., C. Mahler, A. Castaneda \& H. Aguilar 2020. The Impact of COVID-19 (Coronavirus) on Global Poverty: Why Sub-Saharan Africa Might be the Region Hardest Hit. World Health Organisation, April 20. Available at: https://blogs.worldbank.org/opendata/impact-covid-19coronavirus-global-poverty-why-sub-saharan-africa-might-be-regionhardes (Accessed 22 October 2020)

Goddard, W. \& S. Melville 2004. Research Methodology: An Introduction. $2^{\text {nd }}$ Edition, Oxford: Blackwell Publishing.

Human Sciences Research Council 2020 The Higher Education Department says the Financial Impact of the Covid-19 Pandemic on University Expenditure is over R3.8 Billion. August 11. Available at: http://www.hsrc.ac.za/en/news/media-and-covid19/covid19-impact-onsa-universities (Accessed 22 October 2020.) 
Understanding the Effects of COVID-19 on Universities in South Africa

Husby A. \& G. Modinos 2020. COVID-19: Research after the Pandemic. Nature 580,7803:185. https://doi.org/10.1038/d41586-020-01031-2 PMid:32265567

IOL. 2020. No Campus-based Academic Activity at Tertiary Institutions, Confirms Blade Nzimande. April 30 Available at:

https://www.iol.co.za/news/politics/no-campus-based-academic-activityat-tertiary-institutions-confirms-blade-nzimande-47401133 (Accessed on 12 May 2020.)

Lederman, D. 2020. Preparing for a Fall without In-person Classes. Inside Higher Education. Available at: https://www.insidehighered.com/digitallearning/article/2020/04/01/preparing-quietly-fall-semester-withoutperson-instruction (Accessed on 08 May2020.)

Locatelli, R. 2018. Education as a Public and Common Good: Reframing the Governance of Education in a Changing Context. Education Research and Foresight. Working Papers. https://doi.org/10.1007/978-3-030-24801$\underline{75}$

Lodico, M.G., D.T. Spaulding \& K.H. Voegtle 2010. Methods in Educational Research: From Theory to Practice. Hoboken, New Jersey: John Wiley $\&$ Sons.

Makupe, B. 2020. How South African Universities are Preparing for Coronavirus. Mail and Guardian March 9. Available at: https://mg.co.za/article/2020-03-09-how-south-african-universities-arepreparing-for-coronavirus/ (Accessed on 09 April 2020.)

Mapanga, C. 2020. Level 4 Lockdown: Students won't Return to Campus, Risk is too Great - Blade Nzimande. April 30. Available at: https://www.news24.com/news24/SouthAfrica/News/level-4-lockdownstudents-wont-return-to-campus- (Accessed on 04 November 2020.)

Molosankwe, B. 2020. UJ Students Reject Planned Online Teaching to Start Next Week. The Star 2020 April 17, News.

Naik, S. 2020. Final-year Medical Students Say Universities Acting 'Recklessly' over In-service Training. May 9. Available at: https://www.iol.co.za/saturday-star/news/final-year-medical-studentssay-universities-acting-recklessly-over-in-service-training-47757516 (Accessed on 12 May 2020.)

National Treasury 2020a. Supplementary Budget Review 2020. Pretoria: National Treasury.

National Treasury 2020b. Budget Review 2020. Pretoria: National Treasury. 
Neuman, W.L. 2003. Social Research Methods: Qualitative and Quantitative Approaches. Boston MA: Allyn and Bacon.

Perkowska, S. 2020. Evidence-based Management. Develop Learning Skills. Complete and consistent. Available at:

https://soldevelofoundation.org/evidence-based-management-developlearning-

skills/?gclid=CjwKCAjwoc_8BRAcEiwAzJevtefjTFrCnXmq_mfhxH8e cJeR7jIkkJ3Xun (Accessed 22 October 2020.)

Pfeffer J. \& R. Sutton 2006. Evidence-Based Management. Harvard Business

Review January. Available at: https://hbr.org/2006/01/evidence-basedmanagement (Accessed on 23 October 2020.)

Powell, K. 2020. Science-ing from Home in the Coronavirus Era. Nature 580,7803: 419 - 421. Available at: http://dx.doi.org/10.1038/d41586-02000935-3 (Accessed on 23 October 2020).

PMid:32218550

Salovey, P. 2020a. COVID-19-Moving Courses Online and Other Significant Updates. Yale University.

Available at: https://covid19.yale.edu/university-announcements-aboutcovid-19/covid-19-moving-courses-online-andother-significant-updates (Accessed on 06 May 2020).

Salovey, P. 2020b. COVID-19 Update - First Confirmed Yale COVID-19 Case: Extending Online Instruction to End of Spring Semester; Campus and Staffing Considerations. Yale University. Available at: https://covid19.yale.edu/university-announcements-about-covid19/covid-19-update-first-confirmed-yalecovid-19-case-extending (Accessed on 06 May 2020.)

Saunders, M., P. Lewis \& A. Thornhill 2012. Research Methods for Business Students. $6^{\text {th }}$ Edition, London: Pearson Education.

Smith, S.U., S. Hayes \& P. Shea 2017. A Critical Review of the Use of Wenger's Community of Practice (CoP) Theoretical Framework in Online and Blended Learning Research, 2000-2014. Online Learning 21,1: 209 237. https://doi.org/10.24059/olj.v21i1.963

Stanford Social Innovation Review 2020. Measurement and Evaluation: Making the Case for Evidence-based Decision-making. Available at: https://ssir.org/articles/entry/making the case for evidence based deci sion_making

(Accessed on 22 October 2020). 
Stein, S. 2019. Beyond Higher Education as we Know It: Gesturing towards De-colonial Horizons of Possibility. Studies in Philosophy and Education 38: 143 - 161. https://doi.org/10.1007/s11217-018-9622-7

USAf. 2020. Public Universities have either Embraced Emergency Teaching/ Learning, or are Getting Ready for the Inevitable, in the COVID-19 Era. Available at: https://www.USAf.ac.za/universities-coronavirus-covid-19updates/ (Accessed on 06 May 2020).

Van der Merwe, C. 2020. Government Promises Laptops for All Needy Students. Research Professional News May 7. Available at: https://www.researchprofessionalnews.com/rr-news-africa-south-2020-

5-government-promises-laptops-for-all-needy-students/ (Accessed on 03 November 2020.)

Vygotsky, L.S. 1978. Mind in Society. Cambridge, MA: Harvard University Press.

Wenger E. 1998. Communities of Practice: Learning, Meaning and Identity.

New York: Cambridge University Press.

https://doi.org/10.1017/CBO9780511803932

Wenger, E. 2010. Communities of Practice and Social Learning Systems: The Career of a Concept. In Blackmore, C. (ed.): Social Learning Systems and Communities of Practice. London: Springer.

https://doi.org/10.1007/978-1-84996-133-2_11

World Bank 2019. South Africa Economic Update - Tertiary Education Enrolment must Rise. Washington, D.C.: World Bank.

Zwelinzima Ndevu

Director School of Public Leadership (SPL)

Stellenbosch University zwelinzima@spl.sun.ac.za 